\title{
Evaluation of Chemical, Functional, Spectral, and Thermal Characteristics of Sargassum wightii and Ulva rigida from Indian Coast
}

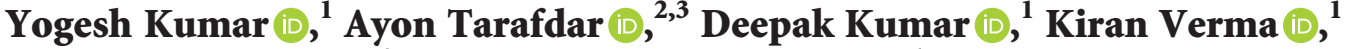 \\ Manjeet Aggarwal $\left(\mathbb{D},{ }^{4}\right.$ and Prarabdh C. Badgujar $\left(\mathbb{D}^{1}\right.$ \\ ${ }^{1}$ Department of Food Science and Technology, National Institute of Food Technology Entrepreneurship and Management, \\ Kundli-131 028, Sonipat, Haryana, India \\ ${ }^{2}$ Department of Food Engineering, National Institute of Food Technology Entrepreneurship and Management, Kundli-131 028, \\ Sonipat, Haryana, India \\ ${ }^{3}$ Livestock Production and Management Section, ICAR-Indian Veterinary Research Institute, Izatnagar, 243122 Bareilly, \\ Uttar Pradesh, India \\ ${ }^{4}$ Department of Basic and Applied Sciences, National Institute of Food Technology Entrepreneurship and Management, \\ Kundli-131 028, Sonipat, Haryana, India
}

Correspondence should be addressed to Prarabdh C. Badgujar; prarabdh.badgujar@gmail.com

Received 24 June 2021; Accepted 17 July 2021; Published 30 July 2021

Academic Editor: Alessandra Durazzo

Copyright ( $\odot 2021$ Yogesh Kumar et al. This is an open access article distributed under the Creative Commons Attribution License, which permits unrestricted use, distribution, and reproduction in any medium, provided the original work is properly cited.

\begin{abstract}
Usage of seaweeds as a functional food/food ingredient is very limited due to paucity of scientific information about variations in the nutritional composition of seaweeds under diverse climatic conditions. Sargassum wightii and Ulva rigida seaweeds are found abundantly on the Southern Indian coastline and were thoroughly evaluated in this work. Crude fiber and lipid of $S$. wightii were higher $(24.93 \pm 0.23 \%$ and $3.09 \pm 0.41 \%$, respectively) as compared to $U$. rigida; however, $U$. rigida had higher crude protein content $(27.11 \pm 0.62 \%)$. Evaluation of mineral and CHNS content indicated that the concentration of potassium, magnesium, and calcium was $1.36 \pm 0.08 \mathrm{mg} / \mathrm{g}, 8.39 \pm 0.80 \mathrm{mg} / \mathrm{g}$, and $14.03 \pm 3.46 \mathrm{mg} / \mathrm{g}$, respectively, that was higher in the $S$. wightii, whereas $U$. rigida contained higher value of iron, carbon, and sulphur $(0.70 \pm 0.13 \mathrm{mg} / \mathrm{g}, 37.72 \pm 4.63 \%$, and $2.61 \pm 0.16 \%$, respectively). Swelling capacity $(19.42 \pm 0.00 \mathrm{~mL} / \mathrm{g} \mathrm{DW}$ to $22.66 \pm 00 \mathrm{~mL} / \mathrm{g} \mathrm{DW})$, water-holding capacity $(6.15 \pm 0.08 \mathrm{~g} / \mathrm{g} \mathrm{DW}$ to $6.38 \pm 0.14 \mathrm{~g} / \mathrm{g}$ $\mathrm{DW})$, and oil-holding capacity $(2.96 \pm 0.13 \mathrm{~g} / \mathrm{g} \mathrm{DW})$ of $U$. rigida were significantly $(p<0.05)$ higher as compared to $S$. wightii. It was observed from DSC thermograms that $S$. wightii can be safely processed for food formulations even at a temperature of $134^{\circ} \mathrm{C}$. The thermograms also revealed changes in the sulphated polysaccharide (fucoidan) profile due to the presence of hydroxyl and carboxyl groups with denaturation of proteins. TGA of $S$. wightii and $U$. rigida showed degradation temperature within the range of $200-300^{\circ} \mathrm{C}$ due to divergent polysaccharide compositions. FTIR spectroscopy suggested the presence of phenolic groups in both seaweeds (at $1219 \mathrm{~cm}^{-1}$ ). Results of the study suggested that the manufacturing of functional food products from seaweeds could be beneficial and may aid in social upliftment of cultivators/fishermen.
\end{abstract}

\section{Introduction}

Seaweeds are potential source of bioactive compounds, phytochemicals, polysaccharides, dietary fibre, $\omega$-3 fatty acids, essential amino acids, vitamins, and minerals such as calcium, potassium, sodium, and phosphorous [1]. Bioactive compounds extracted from seaweeds have many therapeutic properties such as antioxidant, anti-inflammatory, and antimicrobial activity [2]. The proximate composition, nutrients, and bioactive compounds present in seaweeds depend on several factors such as species, oxygen concentration, salinity of water, climatic season, intensity of UV radiation, and area of production [3, 4]. Seaweeds growing under such harsh conditions generate several 
secondary metabolites that prevent their structural damage [5]. Commercially, seaweeds are utilized for extraction of stabilizers, thickening agents, agar, and gelling agents with diverse industrial applications.

Usage of seaweeds in Oriental and some European populations is significant, but not so among the Indian population. Countries like Japan, Malaysia, and France have legalized seaweeds as vegetables and condiments [6]. Indian coastal region is a rich source of seaweeds. Southern and South-eastern coast (Mandapam, Palk of Bay) of India are an industrial hub for seaweed cultivation, harvesting, and processing. Several species of brown, green, and red seaweeds are cultivated, as well as found, abundantly. Some genera of edible seaweeds among these are consumed by the coastal population but not by majority of the mainland people. Also, use of edible seaweeds in processed form is very scarce in India owing to palatability issues and unavailability of scientific data. Seaweeds therefore can be processed to bring them into palatable form, fit for various food applications considering their abundant availability, and miniscule consumption in the Indian diet. Moreover, due to growing consumer demand for nutritious food, seaweed can be easily popularized within the masses after establishing a strong scientific backbone to its merits.

Among brown seaweeds, Sargassum is an important genus. It is a good source of carbohydrate, minerals, proteins, essential amino acids (e.g., arginine, tryptophan, and phenylalanine), $\beta$-carotene, and vitamins [7]. Indian coast has more than 56 Sargassum species, and some species such as Sargassum siliquosum are utilized by local populations as an ingredient in salad, fish soup, and rice dishes [8]. Among Sargassum, S. wightii grows abundantly throughout the year on both eastern and western coasts. Significant variations in the nutritional composition of $S$. wightii have been reported with respect to seasonality and vegetative parts [7]. However, there are not many reports about its spectral and thermal characteristics and its relation with proximate, nutritional composition and functional properties. The present study is an attempt to elucidate these characteristics of $S$. wightii.

Same is the case of green seaweed (Chlorophyta). More than 43 genera of Chlorophyta have been recognized at the Indian coastal region [8]. In the Chlorophyta, Ulva is cultivated majorly. Ulva has various therapeutic properties due to the presence of ulvan, a sulfated polysaccharide that has antioxidant, antitumor, anticoagulant, immunomodulatory, wound dressing, tissue healing, and heavy metals binding ability $[9,10]$. Among Ulva, Ulva rigida is a green macroalgae widely distributed in tropical oceans and Indian coastline. It is widely distributed in the Mandapam and adjacent areas of Tamil Nadu, south-eastern and Gujarat coast of India, respectively [7]. Ulva species is consumed in raw form or in soup preparations among the coastal residents [11].

Despite our best efforts, we could not find a study wherein thermal and spectral properties of these seaweeds are reported, and data regarding these properties shall help in processing of these seaweeds to formulate various processed food products, as well as functional foods/ nutraceuticals. However, ulvan (sulfated polysaccharide) extracted from Ulva lactuca (Monastir-Tunisia Coast) was thermally characterized, and it was reported that these polysaccharides showed stability even at $180^{\circ} \mathrm{C}$, while rhamnose sulphate and uronic acid functional groups were observed through infrared spectroscopy [12]. Thus, the aim of the present study was to catalogue the proximate composition, functional properties, and thermal and spectral attributes of $S$. wightii and $U$. rigida seaweeds. We believe that the results of this investigation will be of immense help to food processing and nutraceuticals industries in order to come up with processed products or functional foods, whereby seaweed consumption can be increased in mainstream population.

\section{Materials and Methods}

2.1. Chemicals. Petroleum ether, boric acid, sodium hydroxide, hydrochloric acid, and nitric acid were purchased from Thermo Fischer, India. Corn oil was procured from Sigma-Aldrich (Bangalore, India). All other solvents and chemicals used were of analytical grade.

\subsection{Seaweed Collection and Processing. Green (Ulva rigida)} and brown (Sargassum wightii) seaweeds were obtained from the seaweed traders from Kanyakumari $\left(8^{\circ} 05^{\prime} 02^{\prime \prime} \mathrm{N}\right.$ $\left.77^{\circ} 32^{\prime} 46^{\prime \prime} \mathrm{E}\right) \mathrm{Tamil} \mathrm{Nadu}$, India, and Mandapam ( $9^{\circ} 17^{\prime} \mathrm{N}$ and $79^{\circ} 11^{\prime}$ E), Tamil Nadu, India, in September 2018 with the help of scientists of the research institute, CSIR-Central Salt and Marine Chemicals Research Institute, Mandapam, India. Collected seaweed was cleaned with tap water to remove epiphytes, sand, and debris and then shade-dried at room temperature up to a total moisture content of $21.53 \pm 0.05 \%$ (wet basis). The shade-dried seaweeds were ground to powder using a mixer-grinder and passed through an 850 micron screen. The dried seaweed powder was stored at $-20^{\circ} \mathrm{C}$ in air tight bags for further analysis.

\subsection{Estimation of Chemical Composition of Seaweeds.} Proximate composition including total carbohydrates, crude fat, crude protein, crude fiber, total ash, and total moisture content of seaweeds was determined according to AOAC [13]. The values are reported in \% dry weight (DW) basis.

\subsection{Functional Properties of Seaweeds}

2.4.1. Swelling Capacity (SWC). Swelling capacity of $U$. rigida and $S$. wightii was measured by bed volume technique [6, 14]. Briefly, $200 \mathrm{mg}$ of dried seaweed powder was taken and mixed with $20 \mathrm{~mL}$ of deionized water and stirred vigorously. The effect of temperature on SWC was measured by keeping tubes at $25^{\circ} \mathrm{C}$ and $37^{\circ} \mathrm{C}$ for $24 \mathrm{~h}$. SWC of the seaweeds was calculated using the following formula: 


$$
\begin{aligned}
\mathrm{SWC}= & \text { initial volume of water }(\mathrm{mL}) \\
& - \text { volume of water after incubation }(\mathrm{mL}) .
\end{aligned}
$$

The swelling volume was expressed as $\mathrm{mL}$ of swollen sample per gram of sample dry weight.

2.4.2. Water Holding Capacity (WHC). Water holding capacity of both seaweeds was measured by a modified centrifugation method $[6,14]$. Briefly, $200 \mathrm{mg}$ of dried seaweed powder was taken and mixed with $20 \mathrm{~mL}$ deionized water in the centrifuge tube. The tubes were kept in an incubator shaker (New Brunswik Scientific, Eppendorf AG, Germany) at $25^{\circ} \mathrm{C}$ and $37^{\circ} \mathrm{C}$ for $24 \mathrm{~h}$. Sample was centrifuged (Sigma 3$18 \mathrm{KS}$, Germany) at $14000 \mathrm{~g}$ at $37^{\circ} \mathrm{C}$ for $30 \mathrm{~min}$, and supernatant was discarded. The wet weight of $U$. rigida and $S$. wightii was noted. Samples were then kept in an oven at $120^{\circ} \mathrm{C}$ for $2 \mathrm{~h}$, and their dry weight was taken. WHC of $U$. rigida and $S$. wightii was calculated using the following formula:

$$
\begin{aligned}
\text { WHC }= & \text { wet weight of the sample }(\mathrm{g}) \\
& - \text { dry weight of the sample }(\mathrm{g}) .
\end{aligned}
$$

WHC was expressed as weight in grams of water held by $1 \mathrm{~g}$ of dried sample.

2.4.3. Oil Holding Capacity (OHC). According to the method of Wong and Cheung [6], OHC of both seaweeds was measured. Briefly, $3 \mathrm{~g}$ of dried seaweed powder was mixed with $10.5 \mathrm{~g}$ of corn oil in a centrifuge tube. Tubes were kept in the shaker for $30 \mathrm{~min}$ at room temperature followed by centrifugation at $2500 \mathrm{~g}$ for $30 \mathrm{~min}$, and oil supernatant was collected. OHC was calculated using the following formula:

$$
\begin{aligned}
\mathrm{OHC}= & \text { initial volume of oil }(\mathrm{g}) \\
& - \text { volume of oil after incubation }(\mathrm{g}) .
\end{aligned}
$$

The OHC was expressed as number of grams of oil held by $1 \mathrm{~g}$ of dried seaweed.

2.5. Determination of Minerals in Seaweeds. Samples were prepared using wet digestion method [15] with minor modifications. Briefly, 0.4-0.5 g sample was taken in a $50 \mathrm{~mL}$ beaker. To this, $1 \mathrm{~mL}$ of hydrogen peroxide was added for oxidation. Sample was digested using $5 \mathrm{~mL}$ concentrated nitric acid (69\%) with constant heating at $70^{\circ} \mathrm{C}$ in a water bath. Digestion was continued for 1.5-2 h till attainment of a pale yellow color. Digested sample was transferred to a $50 \mathrm{~mL}$ volumetric flask, and the volume was adjusted using Milli-Q water. Metal composition in seaweeds was determined using an ICP-OES (Optima 7000 DV, Perkin Elmer). A multielement standard was used for analysis of minerals. The equipment was calibrated using different concentrations of the standard $(5,10,25,50$, and $100 \mathrm{ppb}$ ) in $5 \% \mathrm{HNO}_{3}$. Reference blank was taken as diluted (5\%) $\mathrm{HNO}_{3}$. Analysis was carried out in triplicates. Results were expressed in $\mathrm{mg} / \mathrm{kg}$ of seaweeds.
2.5.1. Estimation of Elemental Content of Seaweeds Using the CHNS Analyzer. Carbon, hydrogen, nitrogen, and sulphur content in the shade-dried seaweed samples were determined using the CHNS/O elemental analyzer (Euro EA Elemental Analyzer, Germany).

2.6. Determination of Thermal Properties. Thermal properties were analyzed using a differential scanning calorimeter (DSC) (NETZSCH, Germany) and thermogravimetric analyzer (TGA) (NETZSCH, Germany). Both experiments were performed under a nitrogen atmosphere. For TGA test, $5-10 \mathrm{mg}$ of the test sample was placed into an aluminum pan, and a scan was performed under a temperature range of 20 to $600^{\circ} \mathrm{C}$. The heating rate was kept at $10^{\circ} \mathrm{C} / \mathrm{min}$. For DSC analysis, approximately $5-10 \mathrm{mg}$ of shade-dried seaweed powder was taken in a DSC aluminum pan and hermetically sealed using a lid. The sealed pan was loaded into the equipment at room temperature. An empty pan was used as reference. Flow rate of nitrogen was adjusted at 60 and $40 \mathrm{~mL} / \mathrm{min}$ in purge lines 1 and 2 , respectively. Heating was linearly ramped from $30^{\circ} \mathrm{C}$ to $250^{\circ} \mathrm{C}$ at a rate of $10^{\circ} \mathrm{C} / \mathrm{min}$.

2.7. Fourier Transform Infrared (FTIR) Spectroscopy. Shade-dried seaweed powder was analyzed using Fourier transform infrared (FTIR) spectrometer (Alpha Bruker, USA) at the wavenumber range of $4000-600 \mathrm{~cm}^{-1}$ with resolution of $4 \mathrm{~cm}^{-1}$ and 22 spectral scans. Samples were analyzed by Attenuated Total Reflectance (ATR) technology using a ZnSe crystal, and the spectrum of each sample was normalized with the background measurement. Smoothening of the sample spectra was done using Opus computer software.

2.8. Statistical Analysis. All measurements were carried out in triplicate (three separate lots of each seaweed species), and the values were reported as mean \pm standard deviation. Data were analyzed with independent sample $t$ test using SPSS statistical software package v.20 (IBM, USA) at 5\% level of significance $(p<0.05)$.

\section{Results and Discussion}

3.1. Chemical Composition. Table 1 shows proximate composition of brown (S. wightii) and green (U. rigida) seaweed. Crude protein content of $S$. wightii $(6.43 \%$ DW) and $U$. rigida $(27.11 \% \mathrm{DW})$ was found to be within the range of that reported for brown (3-15\% DW) [7] and green (10-47\% DW) seaweeds [6], respectively. Also, Balar et al. [16] reported protein content of $U$. rigida collected from Indian coastline in the range of $4.14-26.0 \% \mathrm{DW}$. Crude protein of $U$. rigida showed significantly $(p<0.05)$ higher value as compared to S. wightii. However, the crude protein of the S. wightii was found to be lower than that of other Sargassum species (8-16.9\% DW) [7]. Higher protein in green seaweeds is in agreement with previous reports [17]. Furthermore, the crude protein content of $S$. wightii and $U$. rigida was almost comparable to the same species found in the Saurashtra coast 
TABle 1: Proximate composition (\%) of S. wightii and U. rigida.

\begin{tabular}{lcc}
\hline Composition (\% DW) & S. wightii & U. rigida \\
\hline Crude protein & $6.43 \pm 0.39$ & $27.11 \pm 0.62^{*}$ \\
Total ash & $19.87 \pm 0.34$ & $19.63 \pm 0.63$ \\
Crude fibre & $24.93 \pm 0.23^{*}$ & $18.65 \pm 0.78$ \\
Total carbohydrate & $45.66 \pm 0.50^{*}$ & $31.87 \pm 0.26$ \\
Crude lipid & $3.09 \pm 0.41$ & $2.71 \pm 0.70$ \\
Total moisture & $21.33 \pm 0.05$ & $22.61 \pm 0.80$ \\
\hline
\end{tabular}

Results are expressed as mean $\pm(n=3)$. Values bearing ${ }^{*}$ are significantly different $(p<0.05)$ from the corresponding column/seaweed in an independent sample $t$ test. DW, dry weight.

(Western Indian coast: 8\% DW) and in the Portuguese coast $(29.5 \%$ DW), respectively $[7,18]$. Kasimala et al. [4] reported similar results of protein in brown seaweed, S. subrepandum (6.93\%) collected from Eritrean red sea coast of Gurgussum and Hirgigo bay. Variations in the crude protein content were reported to be proportional to thallus maturation of the $S$. wightii with higher crude protein content in the winter season (January-March) at the time of their developing phase, and lower protein content has been reported in the months of July to September on the southern Indian coast [7]. Thus, crude protein content found in our S. wightii correlates well with the results of Kumar et al. [7]. Similar range of protein content in seaweeds was also reported by Rohani-Ghadikolaei et al. [19]. Protein content has been reported to vary with type of species and seasonal variations $[6,20]$.

Total ash content of S. wightii and U. rigida is observed as $19.87 \%$ DW and $19.63 \%$ DW, respectively, which was comparable to the reports of Wong and Cheung [6]. Total ash content of $U$. rigida was slightly lower than other Ulva species such as $U$. lactuca and $U$. pertusa [1].

Crude fiber content of S. wightii $(24.93 \%$ DW) was significantly $(p<0.05)$ higher than $U$. rigida $(18.65 \% \mathrm{DW})$ (Table 1). Crude fiber of S. wightii was found to be higher than the total dietary fiber of same species of Sargassum, while $U$. rigida showed lower value of crude fiber than other Ulva species [21]. Seaweeds are rich in dietary fibers. Soluble fraction of dietary fibers exhibits important functional properties such as antimutagenic, antioxidant, and anticoagulant $[6,22]$. However, insoluble fibers and their physiological effects need much attention for further analysis.

In the present study, total carbohydrate content of S. wightii $(45.66 \%)$ is significantly $(p<0.05)$ higher than U. rigida (31.87\%) (Table 1). Kumar et al. [7] reported 48.9-57.2\% total carbohydrate content in the thallus portion of the S. wightii (Western Indian coast), which was comparable to the present study and $33.5 \%$ in S. polycystum, $18 \%$ in S. myriocystum, while other species of Sargassum were reported to have higher carbohydrate content such as S. thunbergii (67.2\%) (Jeju Do Island, Korea) and S. vulgare (67.8\%) (Buzios beach in the Northwest of Brazil). Balar et al. [16] reported $16.63-65.93 \%$ DW carbohydrate content in Indian seaweed $U$. rigida. Total carbohydrate content is related to the soluble and insoluble carbohydrate content of the S. wightii (Tamil Nadu, India) and highest values found in March and lowest in July [7].
Lipid content of seaweeds generally ranges from 1 to $3 \%$ [6]. In the present study, crude lipid content of $S$. wightii and $U$. rigida was found to be $3.09 \%$ and $2.71 \%$, respectively (Table 1). However, lipid content of same species of Sargassum was comparable, ranging from 2 to $3 \%$, and other species of Sargassum were found to be less than 1\%; e.g., $0.3 \%$ in S. thunbergii, 3.8\% in S. echinocarpum, and $2.0 \%$ in S. ilicifolium $[7,19]$. Also, same species of $U$. rigida from Portuguese cost showed similar result of lipid content (2\%). Lipid content of other species of Ulva was also comparable to U. fasciata (1.83\%), U. reticulata (2.03\%), and U. lactuca $(3.6 \%)[19,23]$. Wong and Cheung [6] reported $14.6 \%$ lipid content of Ulva lactuca that was lower from the U. rigida, whereas Balbar et al. [16] reported 0.8-3.1\% lipid content in $U$. rigida collected from Indian coastal line. Lipid content of the Sargassum differs with seasonal variation (least increased from July to March) and the species of the seaweed. Young blades and thallus portion of $S$. wightii were reported to have highest and least amounts of lipids, respectively [7].

Moisture is a quality factor in the preservation of food products and affects stability of the food materials [21]. The total moisture content of $S$. wightii $(21.22 \%)$ and $U$. rigida was observed to be $21.22 \%$ and $22.61 \%$, respectively. Syad et al. [21] reported similar value of moisture content of same species of Sargassum (22.4\%). Wong \& Cheung [6] reported lower value $10.6 \%$ of $U$. lactuca than $U$. rigida.

3.2. Functional Properties. Figure 1 illustrates functional properties (SWC, WHC, and OHC) of S. wightii and $U$. rigida. SWC and $\mathrm{WHC}$ of $S$. wightii and $U$. rigida increased with the increase in temperature. At $25^{\circ} \mathrm{C}$, SWC of S. wightii was $12.71 \pm 0 \mathrm{~mL} / \mathrm{g}$ dry weight (DW), which increased to $15.89 \pm 0 \mathrm{~mL} / \mathrm{g} \mathrm{DW}$ at $37^{\circ} \mathrm{C}$. Similarly, WHC of S. wightii increased from $5.83 \pm 0.04 \mathrm{~g} / \mathrm{g} \mathrm{DW}$ (at $25^{\circ} \mathrm{C}$ ) to $5.92 \pm 0.14 \mathrm{~g} / \mathrm{g} \mathrm{DW}\left(\right.$ at $\left.37^{\circ} \mathrm{C}\right)$.

In case of $U$. rigida, the SWC and WHC were $19.42 \pm 0.00 \mathrm{~mL} / \mathrm{g} \mathrm{DW}$ and $6.15 \pm 0.08 \mathrm{~g} / \mathrm{g} \mathrm{DW}$, respectively, at $25^{\circ} \mathrm{C}$, which increased slightly to $22.66 \pm 00 \mathrm{~mL} / \mathrm{g} \mathrm{DW}$ and $6.38 \pm 0.14 \mathrm{~g} / \mathrm{g} \mathrm{DW}$. The value of WHC at $25^{\circ} \mathrm{C}$ and $37^{\circ} \mathrm{C}$ of $U$. rigida is significantly $(p<0.05)$ higher as compared to $S$. wightii. These values are higher than those reported for S. wightii (Gulf of Mannar, India) and U. lactuca (A Ma Wan, Hong Kong) [6, 14, 22].

WHC of $S$. wightii and $U$. rigida was lower than that reported for G. edulis, Hypnea japonica, Hypnea charoides, U. lactuca, Laminaria, and Wakame at $37^{\circ} \mathrm{C}$. WHC value of both seaweeds at similar temperature was higher than the WHC of S. wightii $(5.72 \pm 0.14 \mathrm{~g} / \mathrm{g} \mathrm{DW})$, Fucus $(5.48 \pm 0.42 \mathrm{~g} /$ g DW), and Nori $(5.12 \pm 0.15 \mathrm{~g} / \mathrm{g}$ DW), which showed comparable results $[22,24]$.

SWC and WHC of seaweeds depend largely on the amount of protein and total dietary fibers present in their composition [6]. Also, lesser particle size with more surface area indicates higher WHC [25]. Both SWC and WHC directly affect the texture, mouthfeel, and freshness of the food products. Therefore, these help in avoiding loss of moisture from the products during processing [26]. In this study, SWC and WHC values were observed to increase with 


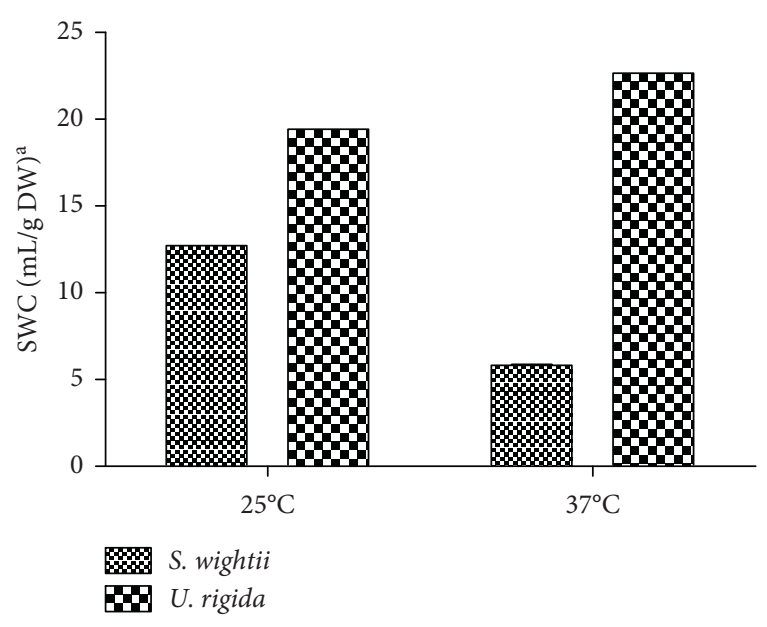

(a)

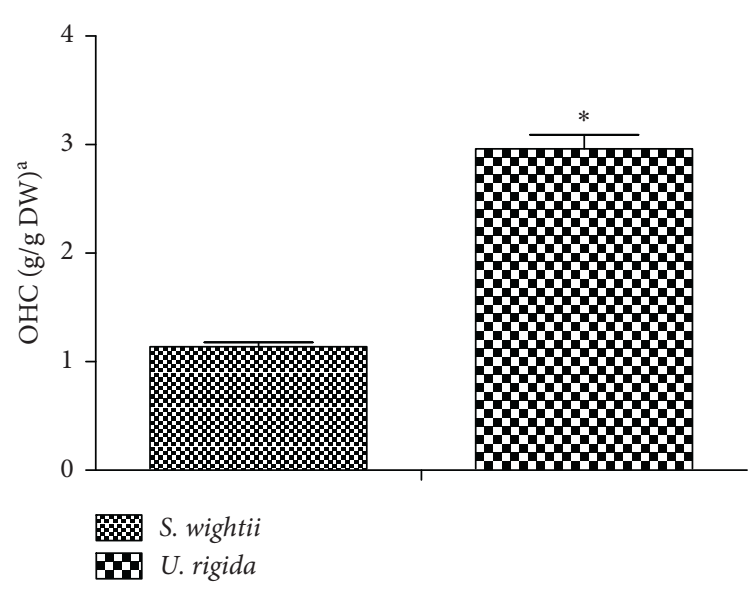

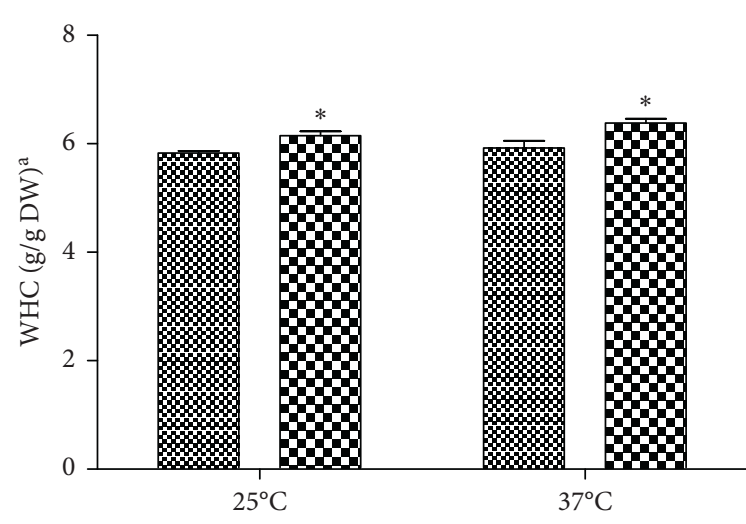

\%. S. wightii E. U. rigida

(b)

(c)

FIgURe 1: Functional properties of seaweeds S. wightii and U. rigida. ${ }^{a}$ Results are expressed as mean \pm SD $(n=3)$. Values bearing ${ }^{*}$ are significantly different $(p<0.05)$ from the corresponding seaweed in an independent sample $t$ test.

temperature, which may be due to the increased solubility of fibers and proteins that contribute to the functional behavior [21]. Among the two seaweeds, U. rigida showed higher SWC and WHC, which shows its potential for use as functional ingredient to modify texture and viscosity, avoid syneresis, and reduce calories [6].

$\mathrm{OHC}$ value of $U$. rigida $(2.96 \pm 0.13 \mathrm{~g} / \mathrm{g} \mathrm{DW})$ was found to be significantly $(p<0.05)$ higher than $S$. wightii $(1.14 \pm 0.04 \mathrm{~g} / \mathrm{g} \mathrm{DW})$ (Table 2). Comparable results were reported for Laminaria, Nori, and G. edulis, while it was higher than that of $H$. japonica, $H$. charoides, and U. lactuca $[14,22,24]$. According to Wong and Cheung [6], the hydrophobicity of proteins helps in fat absorption. The mechanism of $\mathrm{OHC}$ is mainly due to physical entrapment of oil by capillary attraction. Therefore, different proportions of polar side chains of amino acids present on the surface of protein molecules are responsible for variation in $\mathrm{OHC}$ of seaweeds. OHC of seaweeds is also related to hydrophilic nature, overall charge density, and particle size of the individual particles.
TABle 2: Mineral composition of S. wightii and U. rigida analyzed by ICP-OES.

\begin{tabular}{lcc}
\hline \multirow{2}{*}{ Name of the element } & \multicolumn{2}{c}{ Observed concentration $(\mathrm{mg} / \mathrm{g})$} \\
& S. wightii & U. rigida \\
\hline $\mathrm{Mg}$ & $8.39 \pm 0.80^{*}$ & $6.07 \pm 0.49$ \\
$\mathrm{P}$ & $0.32 \pm 0.00$ & $0.44 \pm 0.01^{*}$ \\
$\mathrm{~K}$ & $1.36 \pm 0.08^{*}$ & $0.27 \pm 0.03$ \\
$\mathrm{Ca}$ & $14.03 \pm 3.46^{*}$ & $2.39 \pm 0.17$ \\
$\mathrm{Fe}$ & $0.30 \pm 0.03$ & $0.70 \pm 0.13^{*}$ \\
$\mathrm{Cr}$ & $0.002 \pm 0.00$ & $0.003 \pm 0.00$ \\
$\mathrm{Mn}$ & $0.008 \pm 0.00$ & $0.02 \pm 0.00^{*}$ \\
$\mathrm{Cu}$ & $0.007 \pm 0.00$ & $0.02 \pm 0.01$ \\
\hline
\end{tabular}

Results are expressed as mean $\pm(n=3)$. Values bearing ${ }^{*}$ are significantly different $(p<0.05)$ from the corresponding column/seaweed tested in an independent sample $t$ test.

3.3. Mineral Content. Table 2 shows mineral and trace element analysis of $S$. wightii and $U$. rigida. Analysis revealed higher potassium $(1.36 \pm 0.08)$ and calcium $(14.03 \pm 3.46)$ 
content in S. wightii as compared to U. rigida. Potassium plays an important role in electrical conductivity and functioning of brain [21], whereas seaweed-sourced calcium (calcium carbonate) has been reported to be utilized more effectively as compared to cow milk's calcium [23]. U. rigida showed higher magnesium in comparison to $S$. wightii contain. Magnesium plays an important role in functioning of central nervous system and also helps in eliminating the symptoms of Parkinson's and Alzheimer's disease [21]. In addition to macrominerals, both the seaweeds contained trace elements, which also play a major function in the human body. Iron is one of the important trace elements, being a major component of hemoglobin. Iron content in S. wightii was found to be lower $(0.30 \mathrm{mg} / \mathrm{g})$ as compared to U. rigida $(0.70 \mathrm{mg} / \mathrm{g})$. Apart from iron, S. wightii and $U$. rigida had trace elements like chromium, manganese, and copper. Elemental bioaccumulation by seaweeds is affected by season, thallus age, $\mathrm{pH}$, habitat, and exposure to residential and industrial effluents [23]. In the present study, S. wightii showed lower amounts of potassium, calcium, magnesium, iron, and copper as compared to that reported by Murugaiyan and Sivakumar [22] and Syad et al. [21] for S. wightii collected from Gulf of Mannar, India. This variation could be due to season, time of collection, climatic factors, etc. Ulva rigida showed slightly lower amounts of potassium, calcium, magnesium, iron, manganese, and copper as compared to the same species of Ulva obtained from northwest Iberian, Spain and Portuguese coast [24]. The results of mineral analysis hold significance for use of both seaweeds for nutraceuticals (dietary supplements functional foods industry). Also, Soares et al. [27] reported that subcritical water extracts of Saccorhiza polyschides (brown seaweed) are rich in minerals $(\mathrm{Na}, \mathrm{S}, \mathrm{Ca}$, and $\mathrm{Mg}$ ) that can be used in the development of fertilization products.

3.4. Elemental (CHNS) Composition. Table 3 shows carbon, hydrogen, nitrogen, and sulphur percentage of S. wightii and $U$. rigida. Nitrogen, sulphur, and hydrogen content of $U$. rigida was higher than that of $S$. wightii, while carbon content of $S$. wightii was found to be higher than $U$. rigida. Sulphur content of seaweeds represents amount of sulphur binds with the polysaccharides to form sulfated polysaccharides such as fucoidan in S. wightii and ulvan in U. rigida. These sulfated polysaccharides play critical role in free radical scavenging and show substantial antioxidant activity [12].

\subsection{Decomposition and Glass Transition Temperature of} Seaweeds. Thermogravimetric analysis (TGA) curves for $S$. wightii and $U$. rigida indicate the initial weight loss by water evaporation in the range of $0-100^{\circ} \mathrm{C}$ (U. rigida showed loss at $63.3^{\circ} \mathrm{C}$ ) [28]. The decomposition of $S$. wightii and U. rigida occurred in the temperature range of $200-300^{\circ} \mathrm{C}$, positioned at $282.4^{\circ} \mathrm{C}$ and $273.2^{\circ} \mathrm{C}$, respectively (Figure $2(\mathrm{a})$ ). Besides, $S$. wightii showed its second decomposition at $533.3^{\circ} \mathrm{C}$. Chemical decomposition of organic material initiates at a temperature range of $200-300^{\circ} \mathrm{C}$. At temperature ranges of $220-260^{\circ} \mathrm{C}$ and $315-390^{\circ} \mathrm{C}$, decomposition of
TABLE 3: CHNS elemental analysis of $S$. wightii and U. rigida.

\begin{tabular}{lcccc}
\hline Seaweed & N \% & C \% & H \% & S \% \\
\hline S. wightii & $1.02 \pm 0.06$ & $33.16 \pm 4.89$ & $5.62 \pm 0.79$ & $0.70 \pm 0.06$ \\
U. rigida & $4.33 \pm 0.09$ & $37.72 \pm 4.63$ & $6.94 \pm 0.82$ & $2.61 \pm 0.16$ \\
\hline
\end{tabular}

Results are expressed as mean $\pm \mathrm{SD}(n=3)$.

hemicellulose and cellulose, respectively, takes place [29]. For D-arabinose and D-mannose, pyrolysis reaction occurred at a temperature range of $120-310^{\circ} \mathrm{C}$ and for $\mathrm{D}$-xylose within the range of $140-310^{\circ} \mathrm{C}$ [29], and final degradation above $500^{\circ} \mathrm{C}$ is associated with burning of carbonaceous residues triggered by intense heating [30].

Thermograms of the seaweed powder (S. wightii and $U$. rigida) showed a characteristic endothermic peak indicating their respective glass transition temperatures $\left(T_{g}\right)$ and enthalpy. S. wightii and $U$. rigida exhibited a $T_{g}$ of $134.7^{\circ} \mathrm{C}$ and $78.1{ }^{\circ} \mathrm{C}$, respectively (Figure 2(b)). Glass transition temperature of $U$. rigida was found to be lower than S. wightii. This could be due to inter- and intramolecular hydrogen bonding formed by the polysaccharide hydroxyl and carboxylate groups [18]. Here, the lower $T_{g}$ value of $U$. rigida may be due to higher concentrations of hydroxyl groups of polysaccharides. Rodriguez-Jasso et al. [20] reported that fucoidan extract of Fucus vesiculosus shows weight loss due to dehydration at a temperature range of $25^{\circ} \mathrm{C}$ and $110^{\circ} \mathrm{C}$. They also reported that, at $120^{\circ} \mathrm{C}$, pyrolysis of polysaccharide extract can take place, which could lead to phase transition.

Narrowing of the peaks was observed in both seaweed powders. The area under these peaks was used to determine the enthalpy of both seaweeds. Enthalpy of $S$. wightii and $U$. rigida was calculated as $224.484 \mathrm{~J} / \mathrm{g}$ and $127.030 \mathrm{~J} / \mathrm{g}$, respectively. Increased enthalpy of $S$. wightii indicates more energy required for peptide and glycosidic bond-breakage. Therefore, the net enthalpy indicates the effects of endothermic events (breakdown of hydrogen bonds) [31]. Thermal data of both seaweeds provide appropriate temperature intervals, so that they can be used in the formulation of seaweed-based food products such as noodles. Kumar et al. [31] reported that glass transition temperature $\left(T_{g}\right)$ of seaweed infused coffee varied from $121.3^{\circ} \mathrm{C}$ to $139.3^{\circ} \mathrm{C}$ that changes the flavor of seaweed infused coffee with increase in $T_{g}$. Therefore, only a specific range of temperature $\left(<200^{\circ} \mathrm{C}\right)$ is appropriate for product formulation using seaweed, beyond which degradation could take place.

3.6. Functional Group Analysis. Table 4 shows the infrared spectrum analysis of the seaweeds in the form of $\%$ absorbance versus wave number $(\nu)$. S. wightii and $U$. rigida showed weak absorption peak above $3600 \mathrm{~cm}^{-1}$ which may be due to the presence of $\mathrm{O}-\mathrm{H}$ stretching bend, which shows specific pattern of hydrated inorganic compounds [31]. Strong absorption peak was observed above $3200 \mathrm{~cm}^{-1}$ in $U$. rigida, while $S$. wightii showed weak absorption peak corresponding to $\mathrm{N}-\mathrm{H}$ and $\mathrm{O}-\mathrm{H}$ stretching possibly due to the presence of polysaccharides and amino acids, native to 


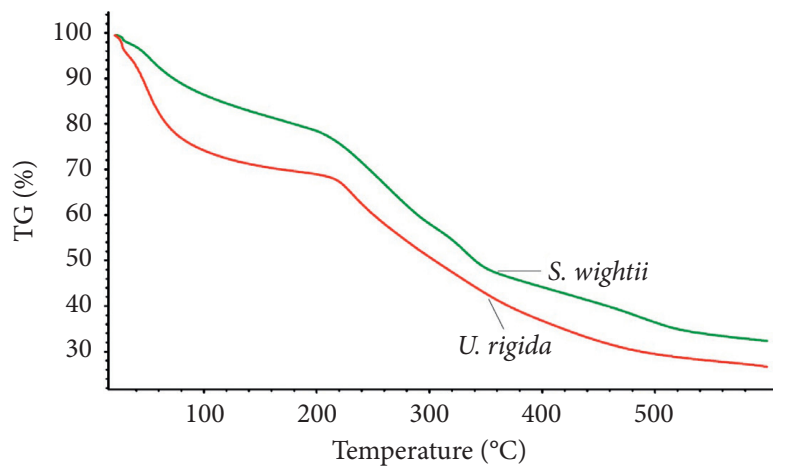

(a)

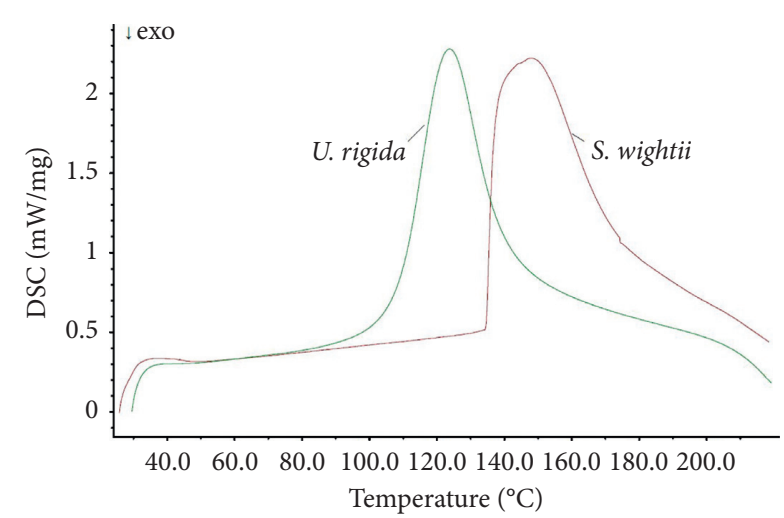

(b)

Figure 2: Thermograms of $S$. wightii and U. rigida from (a) TGA $\left(20^{\circ} \mathrm{C}\right.$ to $\left.600^{\circ} \mathrm{C}\right)$ and (b) DSC $\left(25^{\circ} \mathrm{C}\right.$ to $\left.250^{\circ} \mathrm{C}\right)$.

TABLE 4: FTIR absorption frequencies and functional group of Sargassum wightii and Ulva rigida.

\begin{tabular}{|c|c|c|c|c|}
\hline \multicolumn{2}{|c|}{ Wavenumber } & \multirow{2}{*}{ Functional group } & \multirow{2}{*}{ Compounds } & \multirow{2}{*}{ References } \\
\hline S. wightii & $U$. rigida & & & \\
\hline 3859 & - & \multirow{4}{*}{ OH-stretching } & \multirow{4}{*}{ Alcohol } & {$[31]$} \\
\hline 3740 & 3750 & & & {$[31]$} \\
\hline 3669 & - & & & - \\
\hline- & 3245 & & & - \\
\hline 2372 & - & C-O stretching & Phosphorous & {$[10]$} \\
\hline 1684 & 1631 & $\mathrm{C}=\mathrm{O}$ stretching, $\mathrm{N}=\mathrm{O}$ asymmetric stretching & Ester, pectin, amide & [32] \\
\hline 1527 & 1527 & $\mathrm{C}=\mathrm{C}$ stretching & Lignin & {$[32]$} \\
\hline- & 1417 & $\mathrm{C}-\mathrm{O}$ stretching, $\mathrm{O}-\mathrm{H}$ bending & Cutin & [33] \\
\hline- & 1219 & $\mathrm{~S}=\mathrm{O}$ stretching, C-O stretching & Sulphates, phenols & [33] \\
\hline 1023 & 1023 & $\mathrm{~S}=\mathrm{O}$ stretching & Starch and polysaccharides & {$[33]$} \\
\hline- & 842 & $\mathrm{C}-\mathrm{H}$ bending & Glucose, galactose & [33] \\
\hline 699 & 666 & $\mathrm{C}-\mathrm{S}$ stretching, $\mathrm{C}=\mathrm{S}$ stretching & Sulphates & [33] \\
\hline
\end{tabular}

seaweeds [31]. Weak absorption peak was observed above $2300 \mathrm{~cm}^{-1}$ in both seaweeds, which shows presence of C-O stretching. Strong absorption peak was observed above $1600 \mathrm{~cm}^{-1}$ indicating $\mathrm{C}=\mathrm{O}, \mathrm{N}=\mathrm{O}$ stretching in both seaweeds suggesting a sign of ester and amide groups responsible for characteristic flavor of seaweeds [10,32]. Peaks from $1400-1500 \mathrm{~cm}^{-1}$ and $1500-1600 \mathrm{~cm}^{-1}$ indicate several modes of $\mathrm{C}=\mathrm{C}, \mathrm{C}-\mathrm{O}, \mathrm{O}-\mathrm{H}$ stretching, which may be due to the presence of lignin. Peaks above $1200 \mathrm{~cm}^{-1}$ and $650 \mathrm{~cm}^{-1}$ in both seaweeds indicate $\mathrm{S}=\mathrm{O}, \mathrm{C}-\mathrm{O}, \mathrm{C}-\mathrm{S}$, and $\mathrm{C}=\mathrm{S}$ stretching resulting from the sulphate and phenols present in the seaweeds. Strong absorption peak at $1023 \mathrm{~cm}^{-1}$ in both seaweed points to $\mathrm{S}=\mathrm{O}$ stretching indicating the presence of starch and polysaccharides. Weak absorption peak above $800 \mathrm{~cm}^{-1}$ in $U$. rigida corresponds to $\mathrm{C}-\mathrm{H}$ stretching, which may be due to the presence of glucose and galactose [33]. Peaks above $1200 \mathrm{~cm}^{-1}$ in both seaweeds represent the phenol groups that indicate that both seaweeds are flourish in antioxidants, which can be utilized in development of functional food and their extract may be characterized for the bioactive compounds which can be useful in nutraceuticals formulation. It has also been reported that marine macroalgae produces wide variety of volatile organic compounds such as hydrocarbons, terpenes, phenols, alcohols, aldehydes, ketones, esters, fatty acids, and halogen or sulfur-containing compounds, which are responsible for its characteristic flavor and freshness, and these volatile compounds have been well identified by Spanish researchers in $U$. rigida [34].

\section{Conclusions}

The outcome of the present study is that we have very well documented proximate composition, few nutritional attributes, chemicofunctional properties, and thermal as well as spectral characteristics of seaweeds, S. wightii and U. rigida, collected in the month of September 2018 from the Southern coast of India. Both seaweeds were found to be a good source of nutrients such as crude protein, crude fiber, calcium, iron, and sulfur. The three functional properties, viz., SWC, WHC, and $\mathrm{OHC}$, were found to have direct relation with the fiber and proteins in the seaweeds. Also, it was observed that S. wightii can be safely processed up to $134^{\circ} \mathrm{C}$ as seen from the DSC thermograms without any major phase change phenomenon, whereas TGA results revealed that decomposition of organic material takes place within a temperature range of $200-300^{\circ} \mathrm{C}$ for both seaweeds. Therefore, both seaweeds may be utilized to develop fiber rich food products/ 
as an ingredient in products withstanding this much temperature. Moreover, FTIR spectra showed phenolic groups in both seaweeds, suggesting that they can act as potential antioxidants ultimately to be used for the development of functional foods and nutraceuticals. This seems to be the first report mentioning thermal (DSC and TGA) and spectral (FTIR) attributes of these seaweeds. We believe that large scale use of these seaweeds by food industry could raise socioeconomic status of the cultivators/fishermen. Nevertheless, future work shall be directed towards in vivo studies to establish bioavailability of nutrients and polyphenols present in these seaweeds so as to get comprehensive and conclusive data for their pertinent exploitation.

\section{Data Availability}

All data pertaining to this work are included within this article.

\section{Conflicts of Interest}

The authors declare no conflicts of interest.

\section{Acknowledgments}

The authors are grateful to the Ministry of Food Processing Industries, Govt. of India, for granting research project fund (no. Q-11/8/2018-R\&D) to carry out the present work. The authors express their sincere gratitude to Dr. M. Ganesan, Senior Scientist, CSIR Central Salt and Marine Chemicals Research Institute, Mandapam campus, Tamil Nadu, for the kind help extended in procuring Sargassum wightii and Ulva rigida seaweeds. The authors also thank Mr. Ankur, Lab InCharge, CIL, NIFTEM, for his valuable support in the mineral analysis. The authors would also like to mention that one of the co-authors, Dr. Manjeet Aggarwal, who contributed towards this work, had passed away prior to the submission of this manuscript. The authors express thankfulness for her invaluable scientific inputs which will keep guiding them through their future work.

\section{References}

[1] S. Charoensiddhi, A. J. Lorbeer, C. M. M. Franco, P. Su, M. A. Conlon, and W. Zhang, "Process and economic feasibility for the production of functional food from the brown alga Ecklonia radiata," Algal Research, vol. 29, pp. 80-91, 2018.

[2] C. S. Kumar, P. Ganesan, P. V. Suresh, and N. Bhaskar, "Seaweeds as a source of nutritionally beneficial compounds-a review," Journal of Food Science and Technology, vol. 45, no. 1, pp. 1-13, 2008.

[3] R. Zhang, A. K. L. Yuen, M. Magnusson et al., "A comparative assessment of the activity and structure of phlorotannins from the brown seaweed Carpophyllum flexuosum," Algal Research, vol. 29, pp. 130-141, 2018.

[4] M. Kasimala, G. G. Mogos, K. T. Negasi, G. A. Bereket, M. M. Abdu, and H. S. Melake, "Biochemical composition of selected seaweeds from intertidal shallow waters of Southern Red Sea," Indian Journal of Geo-Marine Sciences, vol. 49, no. 7, pp. 1153-1157, 2020.
[5] B. Tanna, B. Choudhary, and A. Mishra, "Metabolite profiling, antioxidant, scavenging and anti-proliferative activities of selected tropical green seaweeds reveal the nutraceutical potential of Caulerpa spp," Algal Research, vol. 36, pp. 96-105, 2018.

[6] K. H. Wong and P. C. K. Cheung, "Nutritional evaluation of some subtropical red and green seaweeds," Food Chemistry, vol. 71, no. 4, pp. 475-482, 2000.

[7] S. Kumar, D. Sahoo, and I. Levine, "Assessment of nutritional value in a brown seaweed Sargassum wightii and their seasonal variations," Algal Research, vol. 9, pp. 117-125, 2015.

[8] V. A. Mantri, M. G. Kavale, and M. A. Kazi, "Seaweed biodiversity of India: reviewing current knowledge to identify gaps, challenges, and opportunities," Diversity, vol. 12, no. 1, p. 13, 2020.

[9] G. Toskas, R.-D. Hund, E. Laourine, C. Cherif, V. Smyrniotopoulos, and V. Roussis, "Nanofibers based on polysaccharides from the green seaweed Ulva rigida," Carbohydrate Polymers, vol. 84, no. 3, pp. 1093-1102, 2011.

[10] J. T. Kidgell, M. Magnusson, R. De Nys, and C. R. K. Glasson, "Ulvan: a systematic review of extraction, composition and function," Algal Research, vol. 39, Article ID 101422, 2019.

[11] M. B. Kasimala, L. Mebrahtu, P. P. Magoha, G. Asgedom, and M. B. Kasimala, "A review on biochemical composition and nutritional aspects of seaweeds," Caribbean Journal of Science, vol. 3, pp. 789-797, 2015.

[12] H. Yaich, A. B. Amira, F. Abbes et al., "Effect of extraction procedures on structural, thermal and antioxidant properties of ulvan from Ulva lactuca collected in Monastir coast," International Journal of Biological Macromolecules, vol. 105, pp. 1430-1439, 2017.

[13] Association of Official Analytical Chemists (AOAC), Official Methods of Analysis, Association of Official Analytical Chemists, Washington, DC, USA, 17th edition, 2000.

[14] R. Sakthivel and K. Pandima Devi, "Evaluation of physicochemical properties, proximate and nutritional composition of Gracilaria edulis collected from Palk Bay," Food Chemistry, vol. 174, pp. 68-74, 2015.

[15] R. Sirohi and J. P. Pandey, "Dilute acid hydrolysis of spoiled wheat grains: analysis of chemical, rheological and spectral characteristics," Bioresource Technology, vol. 283, pp. 53-58, 2019.

[16] N. Balar, P. Sharnagat, P. Kumari, and V. A. Mantri, "Variation in the proximate composition of edible marine macroalga Ulva rigida collected from different coastal zones of India," Journal of Food Science and Technology, vol. 56, no. 10, pp. 4749-4755, 2019.

[17] M. Kumar, P. Kumari, N. Trivedi et al., "Minerals, PUFAs and antioxidant properties of some tropical seaweeds from Saurashtra coast of India," Journal of Applied Phycology, vol. 23, no. 5, pp. 797-810, 2011.

[18] N. Blanco-Pascual, M. P. Montero, and M. C. Gómez-Guillén, "Antioxidant film development from unrefined extracts of brown seaweeds Laminaria digitata and Ascophyllum nodosum," Food Hydrocolloids, vol. 37, pp. 100-110, 2014.

[19] K. Rohani-Ghadikolaei, E. Abdulalian, and W.-K. Ng, "Evaluation of the proximate, fatty acid and mineral composition of representative green, brown and red seaweeds from the Persian Gulf of Iran as potential food and feed resources," Journal of Food Science and Technology, vol. 49, no. 6, pp. 774-780, 2012.

[20] R. M. Rodriguez-Jasso, S. I. Mussatto, L. Pastrana, C. N. Aguilar, and J. A. Teixeira, "Microwave-assisted extraction of sulfated polysaccharides (fucoidan) from brown 
seaweed," Carbohydrate Polymers, vol. 86, no. 3, pp. 1137-1144, 2011.

[21] A. N. Syad, K. P. Shunmugiah, and P. D. Kasi, "Seaweeds as nutritional supplements: analysis of nutritional profile, physicochemical properties and proximate composition of G. acerosa and S. wightii," Biomedicine \& Preventive Nutrition, vol. 3, no. 2, pp. 139-144, 2013.

[22] K. Murugaiyan and K. Sivakumar, "Seasonal variation in elemental composition of Stoechospermum marginatum (Ag.) Kutz and Sargassum wightii (Greville Mscr.) J.G. Agardh in relation to chemical composition of seawater," Colloids and Surfaces B: Biointerfaces, vol. 64, no. 1, pp. 140-144, 2008.

[23] G. Kumar and D. Sahoo, "Effect of seaweed liquid extract on growth and yield of Triticum aestivum var. Pusa Gold," Journal of Applied Phycology, vol. 23, no. 2, pp. 251-255, 2011.

[24] C. Taboada, R. Millã in, and I. Mã-guez, "Composition, nutritional aspects and effect on serum parameters of marine algae Ulva rigida," Journal of the Science of Food and Agriculture, vol. 90, no. 3, pp. 445-449, 2010.

[25] M. H. Waliullah, T. Mu, M. Ma, and J. Chen, "Effects of particle size on structural, physicochemical, and functional properties of potato residue from starch isolation and quality characteristics of residue-based starch noodles," Food Science and Technology International, vol. 27, no. 5, pp. 392-403, 2021.

[26] M. Nikitha and V. Natarajan, "Properties of South-Indian rice cultivars: physicochemical, functional, thermal and cooking characterisation," Journal of Food Science and Technology, vol. 57, no. 11, pp. 4065-4075, 2020.

[27] C. Soares, J. Švarc-Gajić, M. T. Oliva-Teles et al., "Mineral composition of subcritical water extracts of Saccorhiza Pol$y$ schides, a brown seaweed used as fertilizer in the north of Portugal," Journal of Marine Science and Engineering, vol. 8, no. 4, p. 244, 2020.

[28] H. Doh, K. D. Dunno, and W. S. Whiteside, "Preparation of novel seaweed nanocomposite film from brown seaweeds Laminaria japonica and Sargassum natans," Food Hydrocolloids, vol. 105, p. 105744, 2020.

[29] K. Kebelmann, A. Hornung, U. Karsten, and G. Griffiths, "Thermo-chemical behaviour and chemical product formation from Polar seaweeds during intermediate pyrolysis," Journal of Analytical and Applied Pyrolysis, vol. 104, pp. 131-138, 2013.

[30] D. S. Lakshmi, N. Trivedi, and C. R. K. Reddy, "Synthesis and characterization of seaweed cellulose derived carboxymethyl cellulose," Carbohydrate Polymers, vol. 157, pp. 1604-1610, 2017.

[31] Y. Kumar, A. Tarafdar, D. Kumar, and P. C. Badgujar, "Effect of Indian brown seaweed Sargassum wightii as a functional ingredient on the phytochemical content and antioxidant activity of coffee beverage," Journal of Food Science and Technology, vol. 56, no. 10, pp. 4516-4525, 2019.

[32] J. Li, B. Wang, Y. He et al., "A review of the interaction between anthocyanins and proteins," Food Science and Technology International, vol. 27, no. 5, pp. 470-482, 2020.

[33] S. Kannan, "FT-IR and EDS analysis of the seaweeds Sargassum wightii (brown algae) and Gracilaria corticata (red algae)," International Journal of Current Microbiology and Applied Sciences, vol. 3, no. 4, pp. 341-351, 2014.

[34] F. Sánchez-García, A. Mirzayeva, A. Roldán et al., "Evolution of volatile compounds and sensory characteristics of edible green seaweed (Ulva rigida) during storage at different temperatures," Journal of the Science of Food and Agriculture, vol. 99, no. 12, pp. 5475-5482, 2019. 